\title{
Forum on Science and Health Training Program for Neglected and Re- Emerging Diseases
}

\author{
Flávio Rocha da Silva ${ }^{1,2 *}$, Marli Brito M. de Albuquerque Navarro ${ }^{3}$, Alexandre de Oliveira Saísse ${ }^{1}$, Bernardo Elias $^{2}$, Correa Soares ${ }^{3}$ and \\ Salvatore Giovanni De Simone ${ }^{4,5}$
}

${ }^{1}$ Instituto Oswaldo Cruz, Fundação Oswaldo Cruz, Rio de Janeiro, RJ, Brazil

${ }^{2}$ Associação Nacional de Biossegurança, Rio de Janeiro, RJ, Brazil

${ }^{3}$ Núcleo de Biossegurança-Escola Nacional de Saúde Pública, Rio de Janeiro, Brazil

${ }^{4}$ Instituto Nacional de Ciência e Tecnologia de Inovação em Doenças Negligenciadas (INCT-IDN)/Centro de Desenvolvimento Tecnológico em Saúde (CDTS), Fundação

Oswaldo Cruz, Rio de Janeiro, RJ, Brazil

${ }^{5}$ Departamento de Biologia Celular e Molecular, Instituto de Biologia Universidade Federal Fluminense, Niterói, RJ, Brazil

\begin{abstract}
This paper analyzes the impact of initiatives toward raising awareness, refreshing and training by organizing and conducting forums and training courses aimed at health care professionals and community leaders who work in some cities of Rio de Janeiro (extending that initiative to a city in Minas Gerais). It addresses the topic of "neglected and reemerging diseases", which has been previously deemed of interest to interlocutors involved in that proposal, especially representatives of municipal health secretariats and civil associations of a communal nature.

It should be noted that thematic contents and methodological and pedagogical strategies value objective communication that is easy to understand, without compromising scientific quality. Another aim was to expand scientific information as support to amplify communication with the government in order to help develop public policies, which translate as healthcare actions targeting neglected diseases.

Our conclusion is that it is vital for healthcare professionals, community leaders and government representatives to take part in such events in order to discuss and develop collective proposals based on qualified information about the identified themes as local health priorities to minimize the impact and progress of those diseases.
\end{abstract}

Keywords: Neglected diseases; Re-emerging diseases; Public health; Professional training

\section{Introduction}

The most relevant public health programs in global terms highlight how urgent it is to implement resources, including training healthcare professionals and technological innovation as crucial items to develop controls and/or solutions for neglected diseases and for re-emerging diseases, considering how close the two realities are, since neglected diseases have great potential to resurface. Such concerns are included, for instance, in proposals made by institutions such as the World Health Organization, humanitarian organization Doctors without Borders, among others. For neglected diseases, the conceptual summary is that they are associated with scenarios of poverty, precarious life conditions, as a consequence of profound social and economic inequalities, as a historical condition of poor countries and reflected with significant impact on the health of populations.

The denomination "neglected" is originally linked to the fact that large multinational pharmaceutical companies have no interest in making investments on research targeting those diseases. There is also a lack of financial investment from research supporting agencies to enable technological innovation in a significant scale, represented above all by more effective therapeutic resources. It should be noted that many researchers and managers prefer to use the concept of emerging and re-emerging diseases to refer to this group of diseases. This definition is supported by the concept definition. According to Brazil's epidemiological surveillance, emerging and re-emerging diseases are defined "as clinically distinct infectious diseases which have been recently acknowledged, or an unknown disease whose incidence is increasing in a given place or among a specific population. Specific factors of each disease and the location where they emerge need to be taken into account" [1].
The linearity of those concepts hides the notion that emerging and re-emerging diseases across the world are strongly boosted by the interaction of several phenomena. The context in which infectious diseases emerge and re-emerge is complex in nature and involves multiple unpredictable factors; their incidence depends on complex interaction [2].

Strengthening this complexity, emerging and re-emerging diseases compose an international scenario, mainly regarding the growing globalization which favours the identification of global public health hazards, demanding greater attention from authorities and scientific community to set up a global health program, in order to further understand international health standards related to local contexts that may generate efficient health policies that consider political, economic and social differences between countries. For instance, the tragical Ebola virus epidemic on the African west coast, showed the risk of turning it into a pandemic, having gathered international health authorities to contain spread of the virus worldwide [3].

However, the importance of formulating specific health actions

*Corresponding author: Flávio Rocha da Silva, Instituto Oswaldo Cruz, Fundação Oswaldo Cruz, Rio de Janeiro, RJ, Brazil, Associação Nacional de Biossegurança, Rio de Janeiro, RJ, Brazil, Tel: 55 21-3865-8181; E-mail: flavio.rocha@ioc.fiocruz.br

Received September 24, 2014; Accepted December 22, 2014; Published December 24, 2014

Citation: da Silva FR, de Albuquerque Navarro MBM, de Oliveira Saísse A, Elias B, Soares C (2014) Forum on Science and Health Training Program for Neglected and Re-Emerging Diseases. J Biosafety Health Educ 2: 126. doi:10.4172/23320893.1000126

Copyright: @ 2014 da Silva FR, et al. This is an open-access article distributed under the terms of the Creative Commons Attribution License, which permits unrestricted use, distribution, and reproduction in any medium, provided the original author and source are credited. 
to contain the disease in African countries must be considered as political singularities, everyone with its own socioeconomic and cultural heritage. Let us also point out that Ebola vírus outbreaks are recurrent, having ocurred in 1976, 1994-95 and in 2014. Re-emergence of infectious diseaes, mainly those highly transmisssible, may impact negatively over the affected countries interfering in their comercial relations, sovereignity, safety, security, tourism and environment matters [3].

These contexts point out to the need for educational and health professionals training to make them understand the big effect that infectious diseases may have to the world, choosing among several strategies able to mitigate harm caused by such diseases spread. Ethical issues should also be regarded, specially those related to inequity in distribution of resources as well as the issues requiring decisionmaking skills within the field of complexity.

Supported by those contexts and conceptual indicators, researchers of InstitutoOswaldo Cruz/FIOCRUZ listed "exploratory" goals as a starting point and conducted a survey from 2010 to 2013 on skills, knowledge and experience necessary to establish a diagnosis and/ or suspicion of neglected diseases in some cities of Rio de Janeiro. It was also important to enable those diseases to be recorded as reemerging or emerging, with the purpose of expanding adequate treatment and relevant communication. The analysis of data obtained during visits, conversations with healthcare professionals and patient care observations resulted in the discovery that there was a lack of techniques, materials, training and continuing professional education toward noticing, suspecting, diagnosis, treatment and communication of neglected and/or emerging and re-emerging diseases.

After the initiative's subject of concern was identified, project "Ciência e SaúdeItinerante" was organized with the support of supervisors from the Teaching Department of InstitutoOswaldo Cruz -FIOCRUZ and participation of professionals from several healthcare institutions. The aim was to spread knowledge about emerging, reemerging and/or neglected diseases.

The project set the following three goals: developing knowledge about neglected, emerging and re-emerging diseases; training students and healthcare professionals using relevant information about scientific and technological development; improving the scientific knowledge of teachers in public schools by active participation in science and health forums, sharing qualified information about science, health and technology for the population through community associations.

\section{Preparing strategies to refresh knowledge and for training: forum and symposium}

Motivated by an assessment of contexts that indicates the need to provide better quality healthcare services in Brazil, especially considering the universal nature of our Unified Health System - SUS, important considerations make it imperative to develop initiatives that translate into programs targeting training public healthcare professionals that work in several healthcare services. L'Abbate believes that any professional who works in a healthcare setting must systematically refresh and improve concepts and practices that reflect innovative knowledge and concepts, especially in the fields of Epidemiology and Social Sciences, in order to understand politicalinstitutional determinants of how the Brazilian healthcare system is organized, in addition to acquiring technical domain over their several areas of work. Based on that affirmation, it is relevant to provide room for reflection that will encourage people to develop critical perceptions of the daily activities experienced by professionals in addition to absorbing knowledge that represents an expansion of skills that will translate into an increase in the quality of care provided to the population [4].

Guided by this perspective, our account makes an analytical presentation of the proposition that resulted in organizing spaces for reflection that would encourage discussions based on the daily activities of public healthcare professionals in some cities of Rio de Janeiro. With the purpose of achieving the goal of systematic training as a means to improve the quality of services, the following events were organized: Science and Health Forum and Training Course for professionals who work in public health and for community leaders.

Health and Science forums were supported by partnerships with Health Secretariats of the Cities of Paraty/RJ, Angra dos Reis/RJ, and with the involvement of a City in Minas Gerais State, Rio Preto, in addition to other institutions, such as Centro IntegradoEmpresaEscola/ RJ(CIEE) and Fiocruz, through the addition of the "Mata Atlântica" campus in Jacarepaguá.

Debated subjects were established with the participation of several local interlocutors in order to address issues that were part of those realities. Valued criteria included the needs and concerns of regions that show the potential or clear conditions or epidemiological conditions and realities that are well defined in terms of neglected and/or emerging and re-emerging diseases, considering as relevant information provided by Municipal Health Secretariats of each city and the institutions involved. It should be noted that the target audience consisted of students, healthcare professionals and community leaders.

\section{Training course}

The forums proved to be extremely important in building a proposal for 8-hour Training Courses. They allowed vital assessments used in thematic, methodological and pedagogical proposals, in addition to other strategies that were able to increase participants' interest and encourage new initiatives. Therefore, themes and methodologies for presentation sparked significant interest among healthcare professionals. They also expressed a wish to organize a few initiatives targeting greater epidemiological visibility for the region and expanding knowledge about neglected and/or emerging and re-emerging diseases in order to broaden the view on solutions for problems that are in the realm of public health, of health education and prevention, with the additional aim of raising awareness among the population about the importance of adopting habits that will translate into prevention goals, in addition to establishing a dialog with the government in order to enable public policies, reflected in healthcare action toward neglected diseases.

\section{Strategies organizational procedures}

While preparing the contents of presentations, we valued explanatory pedagogical resources whose language was easy to understand, without prejudice to their scientific precision. We should also mention that the thematic universe was established with the contribution of representatives of institutions involved, noting the public health and scientific knowledge needs that were expressed by the Cities and other participating institutions. We also paid special attention to the relevance of information published by highly credible institutions in the field of health, such as the World Health Organization (WHO), the Ministry of Health (MS), the Centers for Disease Control (CDC) and humanitarian organization Doctors without Borders (MSF). Descriptive talks were given, with practical examples of how to apply scientific knowledge. 
Course materials were provided to participants with the addressed topics, with the aim to share theoretical and practical reference contents. It should be noted that those materials were tailored to the demands expressed by participants. We should also note that such events, forums and refresher and training courses also targeted the goal of training multipliers, in an attempt to cater to local demand identified among students, healthcare professionals and community leaders.

\section{Results}

Three editions of the Science and Health Forum were held between 2010/2012 in partnership with the Paraty City government (RJ), through its Health Secretariat. Forums were aimed at encouraging healthcare professional training in the Costa Verde area on infectious and parasitic diseases and/or neglected, emerging and re-emerging diseases. We intensified collaboration movements with healthcare professionals in those cities, in order to establish intentions toward continuing education and favoring issues regarding emerging, reemerging and neglected diseases, with special mention to greater demand for knowledge about the following diseases: leishmaniasis, Hansen's disease, viral hepatites, pertussis, in addition to demand for information on vaccines. Information on possible further qualifications on other levels of post-graduate studies with respect to the issues addressed was deemed relevant. In quantitative terms, the first edition of the event in 2010 brought together 150 formally registered participants and a significant number of unregistered participants. Other events unfolding as a result of those partnerships were also organized: refresher courses in epidemiology, diagnosis and treatment of tuberculosis in 2010 and the course on epidemiological aspects, social impact and treatment of Hansen's disease in 2012 [5].

Another important development arose from the need expressed by Municipal Secretariats with respect to improving and training healthcare professionals who work with diagnosis and prevention of Sexually Transmitted Diseases (STDs). This demand is supported by demonstrative data that show a gradual increase of those conditions in the regions of Paraty and Angra dos Reis (Costa Verde in Rio de Janeiro State). Building on this concern and on the continuing partnership with Paraty's Health Secretariat, we held the III Science and Health Forum of Costa Verde in 2012. This expansion of partnerships included other specialists from research, teaching and service provider institutions, such as: EscolaNacional de SaúdePública (ENSP/Fiocruz), Fiocruz Mata Atlântica campus, Hospital Central do Exército (HCE), Universidade Federal do Rio de Janeiro (UFRJ), Universidade Federal Fluminense (UFF). The themes were expanded to include concerns regarding diagnosis, basic family care and neglected diseases training (Table 1) [5].

In the City of Angra dos Reis (RJ) the partnership also relied on contributions from Fundação de Saúde de Angra dos Reis (FUSAR), aiming to organize and stage the I Science and Health Forum in that City, one of the largest in the Costa Verde region. This Forum aimed at expanding the debate on the contexts of some neglected diseases, highlighting the approaches of public policies in the region and their ability to promote discussions about the health problems faced by the city $[5,6]$.

The themes of the talks given at the event were: "Neglected diseases - expression of poverty and inequality"; "Aspects of the ecology of vectors of leishmaniasis in Ilha Grande", "Leishmaniasis in Rio de Janeiro State"; "Tuberculosis in Rio de Janeiro"; "Sexually Transmitted Diseases: HTLV, HPV in women and waiting for SUS vaccination"; "Strategies to control STDs and AIDS in basic care"; "Biosafety for healthcare professionals". The event had 157 health professionals, with: 24 doctors, 40 nurses, 12 pharmacists, 4 biologists, 2 dentists, 10 nursing technicians and 65 professionals from Fundação de Saúde de Angra dos Reis.

The city of Rio Preto, in Minas Gerais' Mata Mineira zone and outside Rio de Janeiro State, showed great interest in the training program. The Zona da Mata region (MG) gathers over 37 cities. Several of those cities have high incidences of some neglected diseases. Based on this context, in 2011 we held the I Emerging, Re-emerging and Neglected Diseases Symposium. Other themes addressed based on local interests included: "the impact of pertussis in Brazil"; "leishmaniasis epidemiology and vectors in Brazil"; "epidemiology of dengue fever and its vectors"; "clinical and therapeutic care of rational states and collateral effects of polychemotherapy in patients with Hansen's disease"; "rabies and antirabies care in humans"; "biosafety in healthcare" [5].

In 2012 there was a Science and Health Forum edition in Rio Preto, which also included healthcare professionals, students and locals. The program established themes about public health issues and diseases such as leishmaniasis, meningitis, spotted fever, parasitoses, accidents with poisonous animals and biotechnological applications in the diagnosis of infectious-parasitic diseases.

The event gathered approximately 120 healthcare professionals, students and locals, in order to share knowledge about epidemiological aspects of infectious and parasitic diseases, in addition to addressing important issues on health and life conditions of the population. According to researcher Alba Valéria Machado, who gave the talk "Epidemiology of Leishmaniasis", the I Forum of Zona da Mata contributed to raising awareness of professionals and the population on aspects related to medically relevant diseases? The researcher thus said: "The Forum helped raise awareness among healthcare professionals and the population with respect to diseases that affect the region" (Table 2) [6].

In the city of Rio de Janeiro there were two events to raise awareness

\begin{tabular}{|c|c|c|c|c|c|}
\hline & $\begin{array}{c}\text { I Forum } \\
\text { Year: 2010 }\end{array}$ & $\begin{array}{c}\text { II Forum } \\
\text { Year: 2011 }\end{array}$ & $\begin{array}{c}\text { III Forum } \\
\text { Year: 2013 }\end{array}$ & $\begin{array}{c}\text { Course on } \\
\text { tuberculosis }\end{array}$ & $\begin{array}{c}\text { Course on } \\
\text { Hansen's } \\
\text { disease }\end{array}$ \\
\hline Physician & 21 & 26 & 38 & 13 & 5 \\
\hline Nurse & 31 & 45 & 44 & 15 & 14 \\
\hline Pharmacist & 5 & 7 & 8 & 4 & 3 \\
\hline Biologist & 2 & 5 & 9 & 1 & - \\
\hline $\begin{array}{c}\text { Nursing } \\
\text { technician }\end{array}$ & 35 & 23 & 33 & 37 & 24 \\
\hline $\begin{array}{c}\text { Other } \\
\text { occupation }\end{array}$ & 62 & 47 & 12 & 3 & - \\
\hline \begin{tabular}{c} 
Total \\
\hline
\end{tabular} & 156 & 153 & 144 & 73 & 46 \\
\hline
\end{tabular}

Table 1: Number of professionals who took part in events in Paraty.

\begin{tabular}{|c|c|c|}
\hline & I Symposium & I Forum \\
\hline & Year: 2011 & Year: 2012 \\
\hline Physician & 8 & 7 \\
\hline Nurse & 15 & 23 \\
\hline Pharmacists & 16 & 12 \\
\hline Biologist & 7 & 5 \\
\hline Veterinarian & 13 & 15 \\
\hline Teachers & 10 & 19 \\
\hline $\begin{array}{c}\text { Other health professionals } \\
\text { and students }\end{array}$ & 40 & 24 \\
\hline Total & 109 & 136 \\
\hline
\end{tabular}

Table 2: Number of professionals who took part in events in Rio Preto/MG. 
Citation: da Silva FR, de Albuquerque Navarro MBM, de Oliveira Saísse A, Elias B, Soares C (2014) Forum on Science and Health Training Program for Neglected and Re-Emerging Diseases. J Biosafety Health Educ 2: 126. doi:10.4172/2332-0893.1000126

Page 4 of 5

about neglected and re-emerging diseases: the I Symposium on Reemerging and Neglected Diseases for health professionals and students in Rio de Janeiro State and the I Science and Health Forum of Fiocruz in the Mata Atlântica Campus.

The I Symposium on Re-emerging and Neglected Diseases for health professionals and students in Rio de Janeiro State was held in partnership with Centro de IntegraçãoEmpresa-Escola do Rio de Janeiro (CIEE). The event took place in April 2012 and aimed to expand the public's knowledge on the issue. The meeting was part of Expo CIEE Rio2012's events. Exhibitions and reflections on the proposed thematic framework addressed the following diseases: pertussis, Hansen's disease, tuberculosis and leishmaniasis. Such reflections were summarized in the talk "Neglected Diseases: expression of poverty and of inequality". The eventtookplaceatthe Sul América Convention Center, Cidade Nova - Centro - Rio de Janeiro. Over two hundred students and professionals took part in the event [7].

The I Science and Health Forum, which took place in Fiocruz's Mata Atlântica campus in Jacarepaguá, in the West of Rio de Janeiro, gathered 150 people. The event was organized by Fiocruz in partnership with Rio de Janeiro's City Government and the scientific community of InstitutoOswaldo Cruz (IOC/Fiocruz) also joined in.

The topics were adapted to the region's epidemiological profile.
Talks were repeated to achieve this goal. Therefore, the topic, neglected diseases in the context of social and economic inequalities and their historical recurrence in Brazil, was accompanied by more detailed technical and scientific approaches, positioning healthcare issues pertaining to, above all, hepatites. This approach was complemented by a talk on biosafety for healthcare professionals, since data show an important incidence of hepatites in infection accidents among healthcare professionals. As reflections and summary talks there were two roundtables delving deeper into the debate over leishmaniasis, re-emerging bacterial diseases, pertussis, tuberculosis and Hansen's disease.

Stemming from the Forum Fiocuz Mata Atlântica campus event, in the second semester of 2012 there were four professional refresher and development courses addressing leishmaniasis, Hansen's disease, medical mycology and biosafety (Table 3).

In all events eighteen topics were addressed (Table 4) across six forums, three symposiums, six professional development courses, with forty speakers from several health and teaching institutions. A total one thousand five hundred professionals were trained in all events.

The impact of those initiatives was that several other cities in Rio de Janeiro State expressed their wish to hold such events (Forum and Training Course). CIEE and Fiocruz Mata Atlântica scheduled the II

\begin{tabular}{|c|c|c|c|c|c|}
\hline & I Forum Year:2012 & $\begin{array}{c}\text { Course on } \\
\text { Leishmaniasis }\end{array}$ & $\begin{array}{l}\text { Course on } \\
\text { Hansen's Disease }\end{array}$ & Course on Biosafety & $\begin{array}{c}\text { Course on Medical } \\
\text { Mycology }\end{array}$ \\
\hline Physician & 10 & 4 & 6 & 2 & 4 \\
\hline Nurse & 23 & 6 & 4 & 3 & 5 \\
\hline Pharmacists & 12 & 2 & 5 & 2 & 4 \\
\hline Biologist & 15 & 3 & 6 & 5 & 4 \\
\hline Veterinarian & 5 & - & 3 & 1 & 3 \\
\hline Teachers & 10 & 4 & 3 & 6 & 4 \\
\hline $\begin{array}{l}\text { Other professionals and } \\
\text { students }\end{array}$ & 77 & 17 & 26 & 35 & 26 \\
\hline Total & 152 & 36 & 53 & 54 & 50 \\
\hline
\end{tabular}

Table 3: Number of participants at the Forum and refresher courses at Fiocruz Mata Atlântica.

\begin{tabular}{|c|c|c|c|c|c|c|c|c|c|}
\hline & $\begin{array}{l}\text { I Forum } \\
\text { Paraty }\end{array}$ & $\begin{array}{l}\text { II Forum } \\
\text { Paraty }\end{array}$ & $\begin{array}{l}\text { III Forum } \\
\text { Paraty }\end{array}$ & $\begin{array}{c}\text { I Forum } \\
\text { Angrados Reis }\end{array}$ & $\begin{array}{l}\text { I Forum } \\
\text { Rio Preto }\end{array}$ & $\begin{array}{c}\text { I Forum } \\
\text { Fiocruz Mata } \\
\text { Atlantica }\end{array}$ & $\begin{array}{c}\text { I Symposium Rio } \\
\text { Preto }\end{array}$ & $\begin{array}{l}\text { I Symposium } \\
\text { CIEERJ }\end{array}$ & $\begin{array}{l}\text { II Symposium } \\
\text { CIEERJ }\end{array}$ \\
\hline Leishmaniasis & $x$ & $x$ & & $x$ & $x$ & $x$ & $x$ & $x$ & \\
\hline Dengue & & $x$ & & & & & $x$ & & \\
\hline Tuberculosis & & $x$ & & $x$ & & $x$ & & $x$ & $\times$ \\
\hline Hansens's Disease & & & & & & $x$ & & $x$ & \\
\hline Spotted fever & & & & & $x$ & & & & $x$ \\
\hline Pertusis & $x$ & & & & & $x$ & $x$ & $x$ & \\
\hline Meningitis & $x$ & & & & & & $x$ & $x$ & \\
\hline Neglected diseases & & & & $x$ & & $x$ & & & $x$ \\
\hline Rabies & & & & & & & $x$ & & \\
\hline STD & & & $x$ & $x$ & & & & & \\
\hline Hepatitis & & & $x$ & & & & & & \\
\hline Venomous animals & $x$ & & $x$ & & & & & & \\
\hline Public health policies & & & $x$ & $x$ & & & & & \\
\hline Verminosis and & & & $x$ & & $x$ & & & & \\
\hline health promotion & & & & & $x$ & & & & \\
\hline Biotechnological application & & & $x$ & & $x$ & & & & \\
\hline Graduate education & & $x$ & & & & & $x$ & & \\
\hline Vaccines & & $x$ & & & & & & & \\
\hline Head lice & & & & & & & & & $x$ \\
\hline Biosafety & $x$ & & & $x$ & & $x$ & $x$ & & \\
\hline
\end{tabular}

Table 4: Address topics in forums and symposiums. 
Science and Health Forum and the II Symposium on Re-emerging and Neglected diseases for 2013 in Rio de Janeiro.

CIEE chose the Alemão Complex in Rio de Janeiro to host the event in 2013, with the purpose of raising awareness and suggesting proactive actions in those communities in order to encourage preventive initiatives targeting re-emerging and neglected diseases, especially vector-borne diseases, STDs and tuberculosis. The event took place in April 2013 and featured five speakers form different teaching and research institutions: InstitutoOswaldo Cruz, EscolaNacional de SaúdePública and Hospital Federal dos Servidores do Estado. Topics under discussion included neglected and re-emerging diseases in the city of Rio de Janeiro, the rise in tuberculosis cases in Rio de Janeiro State and the spread of head lice and sexually transmitted diseases.

A scientific exhibition took place alongside the event, with interactive course materials as a way to spark interest and development of science and health in the Alemão Complex region. The following institutions took part in the exhibition: InstitutoOswaldo Cruz, Instituto Vital Brazil and Centro IntegradoEmpresaEscola do Rio de Janeiro.

The exhibition featured information about preventing accidents with venomous animals, dengue control, leishmaniasis control and barnacle activity. Videos were also shown on the topics: "The macro and micro world of Aedesaegypti mosquitoes: to fight it we need to know it"; "Aedesaegypti and Aedesalbopictus: a threat in the tropics" and "Triatominae: the link to a disease".

As pro-active action targeting the community who lives in the Alemão Complex, CIEE made a list of all participants so they could be included in all its different professional training and internship programs.

This proposal to raise awareness reached a total of 70 participants, most of which live in the Alemão Complex region, community leaders and university students from different regions, in addition to a significant number of children who interacted motivated by the activities suggested by the scientific exhibition [8].

The main legacy left by scientific events held in cities and at the institutions involved was affirming the need to continue initiatives to train healthcare professionals, especially with respect to neglected and re-emerging diseases.

It should be conclusively noted that a few topics were re-edited and adapted to the needs of events as they unfolded, such as exhibitions on leishmaniasis and biosafety. Other subjects such as STDs were specified as demands from the cities of Paraty and Angra dos Reis. According to the criterion of thematic adaptation to local demands, the Rio PretoMG city government expressed interest on the following subjects: spotted fever and meningitis (Table 4).

The analysis of this process highlights the need to develop policies to train new healthcare professionals, emphasizing the importance of neglected and re-emerging diseases and the fact that many healthcare professionals who took part in the events expressed their difficulty recognizing those diseases during routine activities in healthcare units where they worked.
In professional refresher courses held after the forums, the need for continuing professional development became clear, especially about diseases such as tuberculosis, for instance, for which it was thought there was enough training for healthcare professionals. In fact, there are significant vulnerabilities, especially with respect to shortcomings regarding biosafety guidelines, in addition to knowledge on the new treatment program adopted by the Ministry of Health. Such vulnerability factors were highlighted by participants, such as outdated knowledge that interferes with professional performance and quality of care.

In summary, training programs targeting neglected and reemerging diseases made a real contribution to local public policies. Therefore, the Training Program supported by the events described above should be extended to include other cities, and through the proposed topics meeting possible needs identified in academic education and in the process of developing scientific skills and practical actions required by healthcare professionals in their daily activities.

We emphasize that healthcare professionals must have constant access to room for reflection that will also encourage critical expression of daily experiences, revealing their views, concerns, suggestions, expressing creative proposals of people who build quality and ethics.

Our conclusion is that it is vital for healthcare professionals, community leaders and representatives of resident associations to take part in such events in order to discuss and develop collective proposals based on qualified information about the presented themes aiming to spread that information and promote preventive actions targeting neglected and re-emerging diseases in their communities, thus minimizing the impact and progress of those diseases.

\section{References}

1. Ministry of Health (2014) Brasil.

2. Souzaw, Doenças negligenciadas (2010) Neglected Diseases:Science and technology for national development strategic studies. Rio de Janeiro: Academia Brasileira de Ciências, pp. 56.

3. Emerging and Re-emerging Infectious Diseases (1999) BSCS, Mark Dabling Blvd, Colorado Springs.

4. Solange abbate L(1999) Education and Health Services: assaying capacitybuilding of health professionals. Cad. Saúde Pública, Rio de Janeiro 15:15-27.

5. Fundação (2013) Oswaldo Cruz Foundation \& Institute.

6. Prefeitura (2013) Angra dos Reis City mayorship (Municipality).

7. Integrated Enterprise and School Centre (2013).

8. Folha (2013) Education NEWS LETTER. 